\title{
Geographical distribution of sporotrichosis in the municipality of Campos dos Goytacazes, Rio de Janeiro
}

\author{
Distribuição geográfica da esporotricose no munícipio de \\ Campos dos Goytacazes, Rio de Janeiro
}

\author{
Gabriela Martins Pereira** (1), Aline de Oliveira Félix ${ }^{2}$ (D) , Adriana Jardim de Almeida ${ }^{3}$ (D), Giulia Del Giudice ${ }^{4}$ (1), \\ Lorena Costa Araújo ${ }^{4}$ (D), Paula Ramalho Marques ${ }^{4}$ (1) \& Olney Vieira-da-Motta ${ }^{3}$ (1) \\ Veterinarian, Universidade Estadual do Norte Fluminense Darcy Ribeiro (UENF), Campus Campos dos Goytacazes, RJ, Brazil. \\ Veterinarian, Resident, Programa de Residência em Medicina Veterinária, Laboratório de Patologia Animal, UENF, Campus \\ Campos dos Goytacazes, RJ, Brazil. \\ ${ }^{3}$ Veterinarian DSc. Departamento de Medicina Veterinária, UENF, Campus Campos dos Goytacazes, RJ, Brazil. \\ ${ }^{4}$ Undergraduate in Veterinary Medicine, UENF, Campus Campos dos Goytacazes, RJ, Brazil.
}

\begin{abstract}
Sporotrichosis is a cutaneous mycosis, it`s etiological agent belongs to the genus Sporothrix. The zoonotic transmission has become the major form of the disease aquisition in Brazil, and the state of Rio de Janeiro has been pointed as the epicenter of the epidemic of sporotrichosis in the country. The notifications of positive cases are currently rising, both in humans and domestic animals, so that the disease is related to hospitalizations and deaths in Brazil, demonstrating it's relevance to the public health. The objective of this paper is to describe the spacial data of the zoonosis in Campos dos Goytacazes, RJ, demonstrating it's evolution in the period from 2016 to 2019. The diagnosis was made by collecting material from suspected lesions of cats and dogs with the aid of sterile swab and the diagnosis was realized through culture on $4 \%$ Sabouraud dextrose agar plus chloramphenicol and cyclohexamide incubeted at $25-30^{\circ} \mathrm{C}$, for approximately 10 to 15 days. The results demonstrated that there was a wide spread of the disease throughout the city in the period studied, with an increase on the number of positive cases and neighborhoods afected. The high incidence of cases and evolution of the geografical distribution of sporotrichosis in the municipality during the analyzed period reveal great concern related to public health in the region.
\end{abstract}

Keywords: zoonosis, transmission, public health, canines; felines.

\section{Resumo}

A esporotricose é uma micose cutânea, seu agente etiológico pertence ao gênero Sporothrix. A transmissão zoonótica tornou-se a principal forma de aquisição da doença no Brasil, sendo o estado do Rio de Janeiro apontado como o epicentro da epidemia de esporotricose no país. As notificações de casos positivos estão aumentando atualmente, tanto em humanos quanto em animais domésticos, de forma que a doença está relacionada a internações e óbitos no Brasil, demonstrando sua relevância para a saúde pública. O objetivo deste trabalho é descrever os dados espaciais da zoonose em Campos dos Goytacazes, RJ, demonstrando sua evolução no período de 2016 a 2019. O diagnóstico foi feito por meio da coleta de material de lesões suspeitas de cães e gatos com auxílio de swab estéril e o diagnóstico foi realizado por cultura em ágar Sabouraud dextrose $4 \%$ mais cloranfenicol e ciclohexamida incubados a $25-30^{\circ} \mathrm{C}$, por aproximadamente 10 a 15 dias. Os resultados demonstraram que houve ampla disseminação da doença em todo o município no período estudado, com aumento do número de casos positivos e bairros afetados. A alta incidência de casos e a evolução da distribuição geográfica da esporotricose no município no período analisado revelam grande preocupação em relação à saúde pública da região.

Palavras-chave: zoonose, transmissão, saúde pública, caninos, felinos.

\section{B] M \\ Brazilian Journal of Veterinary Medicine \\ p-ISSN 0100-2430 \\ e-ISSN 2527-2179 \\ ○}

How to cite: Pereira, G. M., Félix, A. O., Almeida, A. J., Giudice, G. D., Araújo, L. C., Marques, P. R., \& Vieira-da-Mota, O. (2021). Geographical distribution of sporotrichosis in the municipality of Campos dos Goytacazes, Rio de Janeiro. Brazilian Journal of Veterinary Medicine, 43, e002421. https://doi. org/10.29374/2527-2179.bjvm002421

Received: June 25, 2021.

Accepted: November 15, 2021.

\section{*Correspondence}

Gabriela Martins Pereira

Veterinarian autonomus

Av. Alberto Lamego, 405, bloco CO7, ap. 303 Bairro Parque Califórnia

CEP 28016-811 - Campos dos Goytacazes

(RJ), Brazil

E-mail: gabriela.m.pereira@hotmail.com

Copyright Pereira et al. This is an Open Access article distributed under the terms of the Creative Commons Attribution Licensewhich permits unrestricted non-commercial use, distribution and reproduction in any medium provided the original work is properly cited. 


\section{Introduction}

The sporotrichosis is a cutaneous disease caused by fungi of the Sporothrix spp. complex, with worldwide distribution and characterized by papular and nodular lesions at the beginning of the clinical picture of this disease and, later, by ulcerative-gummy lesions (Lacaz et al., 1998; Larsson, 2011). This fungus can be found in places with abundant organic matter and vegetation (Ettinger \& Feldman, 2000).

In fact, there has been a change regarding the etiological agent and the occurrence of cases where S. brasiliensis is isolated and also prevalent in outbreaks of the sporotrichosis in cats. The species $S$. brasiliensis is classified as the most virulent of the complex and it was restricted to Brazil, however a human case involving a cat was described in Argentina. S. brasiliensis was confirmed as the causative agent through fungal culture and sequence analysis of rDNA. (Etchecopaz et al., 2020; Rodrigues et al., 2013a; Zhou et al., 2014; Rodrigues et al., 2013b). The pathogenicity in the host differs from other species of the complex (Fernandes et al., 2013). The occurrences of zoonotic transmission diagnosed in the last decade are also caused by S. brasiliensis (Rodrigues et al., 2016) and is related to the most severe cases of the disease (Almeida-Paes et al., 2014).

Previously, this disease could be reported as an occupational disease, i.e., being detected in gardeners, carpenters, florists, generally speaking, in the land sectors; however, it is currently evidenced in urban areas (Silva et al., 2012). The classic transmission occurs through trauma caused by contaminated plants and branches (Schubach et al., 2004) and this transmission can be observed worldwide, however, in Brazil, the zoonotic transmission through bites and scratches of infected cats still prevails (Montenegro et al., 2014).

Transmission through contact with animals was considered a rare occurrence (Freitas et al., 2010), however, an extensive number of cases of sporotrichosis in humans and cats have been diagnosed in the city of Rio de Janeiro and its municipalities by the Evandro Chagas Clinical Research Institute (Instituto de Pesquisa Clinica Evandro Chagas (IPEC)) since 1998. The occurrence of the disease in humans was four times higher in pet owners of infected cats, i.e., demonstrating the prevalence of zoonotic transmission, and that, the major risk factor for humans is caused by infected cat (Barros et al., 2008).

Indeed, it is considered the largest epidemic of zoonotic transmission (Schubach et al., 2004). In 2004, Barros et al. (2004) described 178 humans diagnosed with the disease and who were treated between 1998 and 2001 in the state of Rio de Janeiro. Although six patients reported no risk factors that could lead to transmission, $90.7 \%$ of the 172 patients were in household or professional contact with cats with sporotrichosis and 64.5\% reported some type of lesion caused by scratching or biting by cats, prior to the onset of symptoms. Between 1997 and 2007, 1,848 cases of human sporotrichosis were diagnosed and treated in the state of Rio de Janeiro (Silva et al., 2012).

From 1998 to 2015, approximately 5000 cases of human and 5113 cases of cat positive for sporotrichosis were diagnosed at the Oswaldo Cruz Foundation (Fiocruz) in Rio de Janeiro (Gremião et al., 2020), and this data is associated with the high incidence of the disease. Furthermore, a geographical spread of the disease has also occurred in Brazil (Gremião et al., 2017). The sporotrichosis is considered one of the most clinically relevant disease in Latin America (Queiroz-Telles et al., 2011).

According to the Brandolt et al. (2018), the authors could report 101 cases of human sporotrichosis in the southern region of Rio Grande do Sul over a five year period (2012-2017), and these data represent the second largest report of an outbreak of confirmed cases in humans in Brazil.

A study conducted between 1992 and 2015 highlighted that sporotrichosis is a disease related to hospitalizations and deaths throughout Brazil and the disparities became evident in states of Rio de Janeiro, São Paulo and Goiás. In Rio de Janeiro, for instance, 250 hospitalisations and 36 deaths were counted, with a successive increase during the years evaluated (Falcão et al., 2019).

This study aimed to describe the occurrence of sporotrichosis in cats and dogs in Campos dos Goytacazes, in the state of Rio de Janeiro from 2016 to 2019, demonstrating the spread of the disease throughout the city. The survey of spatial data on the disease had not yet been conducted, whereas no data regarding the municipality were presented in other studies in the state of Rio de Janeiro, making clear the contribution of this study to knowledge in the field of epidemiological data on sporotrichosis, in order to implement control and prevention policies. 


\section{Material and methods}

The municipality of Campos dos Goytacazes is located in the North Fluminense of the state of Rio de Janeiro, $274 \mathrm{~km}$ from the state capital. According to the IBGE 2020, the population is estimated at 511168 inhabitants, being the seventh most populous city in the state of Rio de Janeiro. It covers a total area of approximately $4032.5 \mathrm{~km} 2$, and it is one of the biggest municipality in the state. The city has thirteen districts and 122 neighbourhoods.

The research was conducted from June 13, 2016 to December 17, 2019. The cats and dogs with suspected sporotrichosis were attended at the Veterinary Hospital of the Universidade Estadual do Norte Fluminense Darcy Ribeiro (UENF) and this study is part of the extension project "Sporotrichosis in Campos dos Goytacazes: diagnosis, control and prevention".

During the clinical consultation, information was collected for the anamnesis form containing data from the pet owners, such as address, history taking, access to the street, contact with other animals and whether it was neutered. In addition, material was collected with sterile swabs from the lesion for laboratory analysis. After collection, the material was taken to the Laboratory of Animal Health of the Center for Technological Agricultural Sciences where it was transferred to a Petri plates containing culture medium Sabouraud Dextrose Agar at 4\% (Himedia ${ }^{\circledR}$ ) plus Chlorophenicol (50mg/l) and Cyclohexamide (400mg/l-Sigma-Aldrich ${ }^{\circledR}$, USA) and was incubated at $25-30^{\circ} \mathrm{C}$ for $10-15$ days. Slides for direct microscopy were prepared to perform gram staining (Figure 1A and B). The animals were considered positive for sporotrichosis only when the fungus could be identified in both exams.

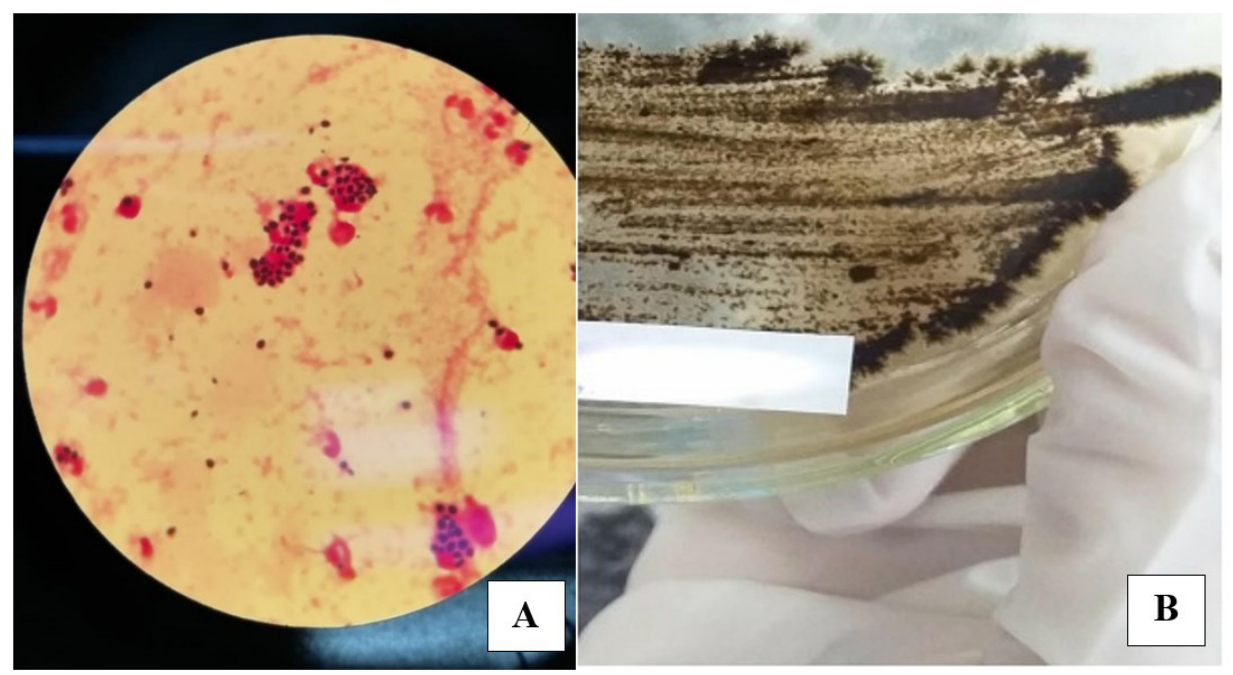

Figure 1. Citology and fungal culture. Note 1A. Direct cytology of a feline lesion performed with Gram stain and 100X objective, showing oval yeast structures compatible with Sporothrix spp. 1B. Macroscopic aspect of the fungus Sporothrix spp. isolated in a Petri dish containing Sabouraud Dextrose agar. Sample collected from a feline/RJ.

Source. Personal archive

When filling in a table in Microsoft Excel, the address notes of the animals' pet owners were included. The positive cases were georeferenced through the address of the files. The mapping concerning the cases of cat sporotrichosis was performed through the MyMaps ${ }^{\oplus}$ tool provided online by Google ${ }^{\circledast}$ for creating custom maps. The research project was approved by the Ethics Committee for Animal Use of the Universidade Estadual do Norte Fluminense Darcy Ribeiro, under number 334.

\section{Results}

From June 13, 2016 to December 17, 2019, 563 dogs and cats positive for sporotrichosis were diagnosed (Figure 2A and B), 23 dogs and 540 cats, when evaluating 122 neighbourhoods and 13 districts of Campos dos Goytacazes, in the state of Rio de Janeiro. Initially, only 23 cases of 


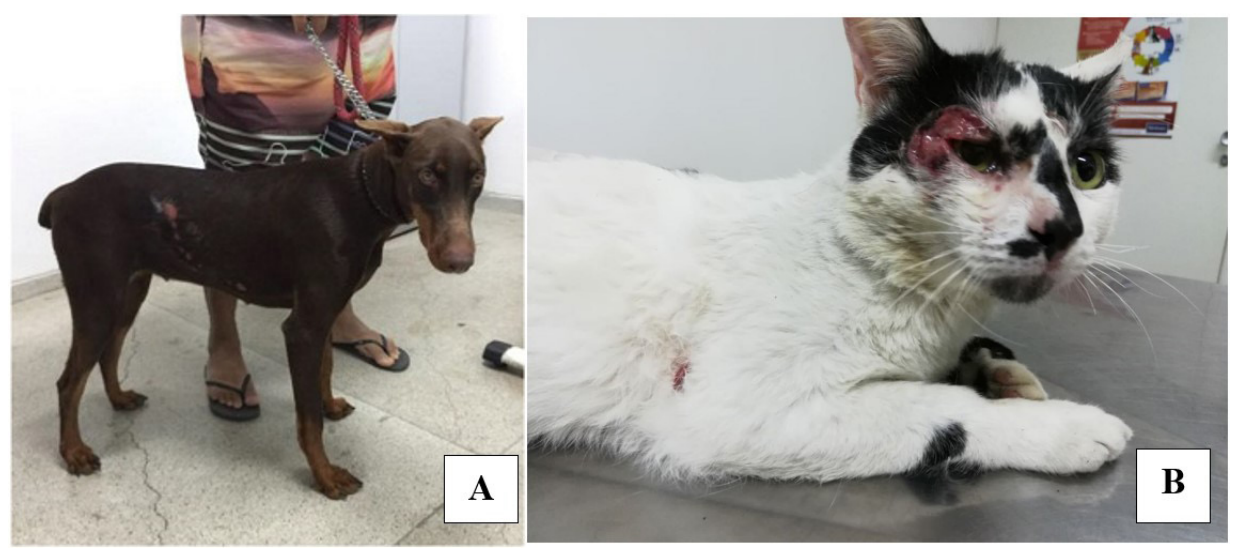

Figure 2. Canine with ulcerated lesions and feline with ocular lesion. Note 2A. Positive canine for sporotrichosis with ulcerated lesions. 2B. Positive feline for sporotrichosis with ulcerated ocular lesion /RJ.

Source. Personal Archive

the disease were diagnosed in animals from only 4.09\% (5) across the city's neighbourhoods in 2016. On the other hand, the positive cases increased to 110 in 2017 and were distributed in $22.13 \%$ (27) across the city's neighborhoods. In 2018, there were 214 positive cases, 213 from city's neighborhoods and one from the districit of Santo Eduardo, i.e., comprising 38.52\% (47) of the affected neighborhoods. In 2019, with the totality of 213 positive cases distributed by neighborhoods and three in the districts of Vila Nova, Santo Eduardo and Travessão, there were 40.98\% (50) of neighborhoods affected in Campos dos Goytacazes. Some pet owners (8) among the positive cases preferred not to inform their addresses. The evolution of the dispersion of the disease over the years can be seen in the Figure 3 .

\section{Discussion}

The most affected neighborhoods were Jockey Club, Parque California, Turf Club, Centro, Goitacazes and Penha. Sporotrichosis has been characterized as a relevant mycosis in neighborhoods of the Metropolitan Region of the state of Rio de Janeiro, which coincides with the lack of infrastructure and sanitation conditions, in addition to being characterized by high levels of population density, low socioeconomic status and urbanization, such as unfinished paving and several vacant lots (Silva et al., 2012), which is consistent with the findings of this study. Places with several plants, dirt areas, inert materials, such as building materials and debris, are considered opportune for the fungus that causes the disease (Barros et al., 2010). Thus, these places are common in the city of Campos dos Goytacazes.

In fact, it could be noted that the evolution regarding the disease initially affected animals from a few neighborhoods and had its distribution spread to 50 neighborhoods of the city, according to the study of Silva et al. (2012) with respect to the disease being present in 36 of the 92 municipalities of the state of Rio de Janeiro. The numbers of positive animals also increased every year, making evident the high contagious and potential disease and difficult management of sporotrichosis. The disease situation in the northern city of the state of Rio de Janeiro is already epidemic, as observed in Rio de Janeiro.

According to Schubach et al. (2004) and Xavier et al. (2004), few studies regarding the epidemiological situation of sporotrichosis in Brazil had been developed at that time. The disease was still considered ignored by the scientific sphere because it was present in only a few geographical areas, despite growing (Bustamante \& Campos, 2004), revealing the importance of the affected regions to map the cases in order to assist in controling the disease.

Indeed, the sporotrichosis was considered a disease of rare occurrence, however the growth in the number of cases and its dispersion in Brazil were neglected for a long period, which suggests high prevalence and uncontrolled growth in several regions (Gremião et al., 2020). 


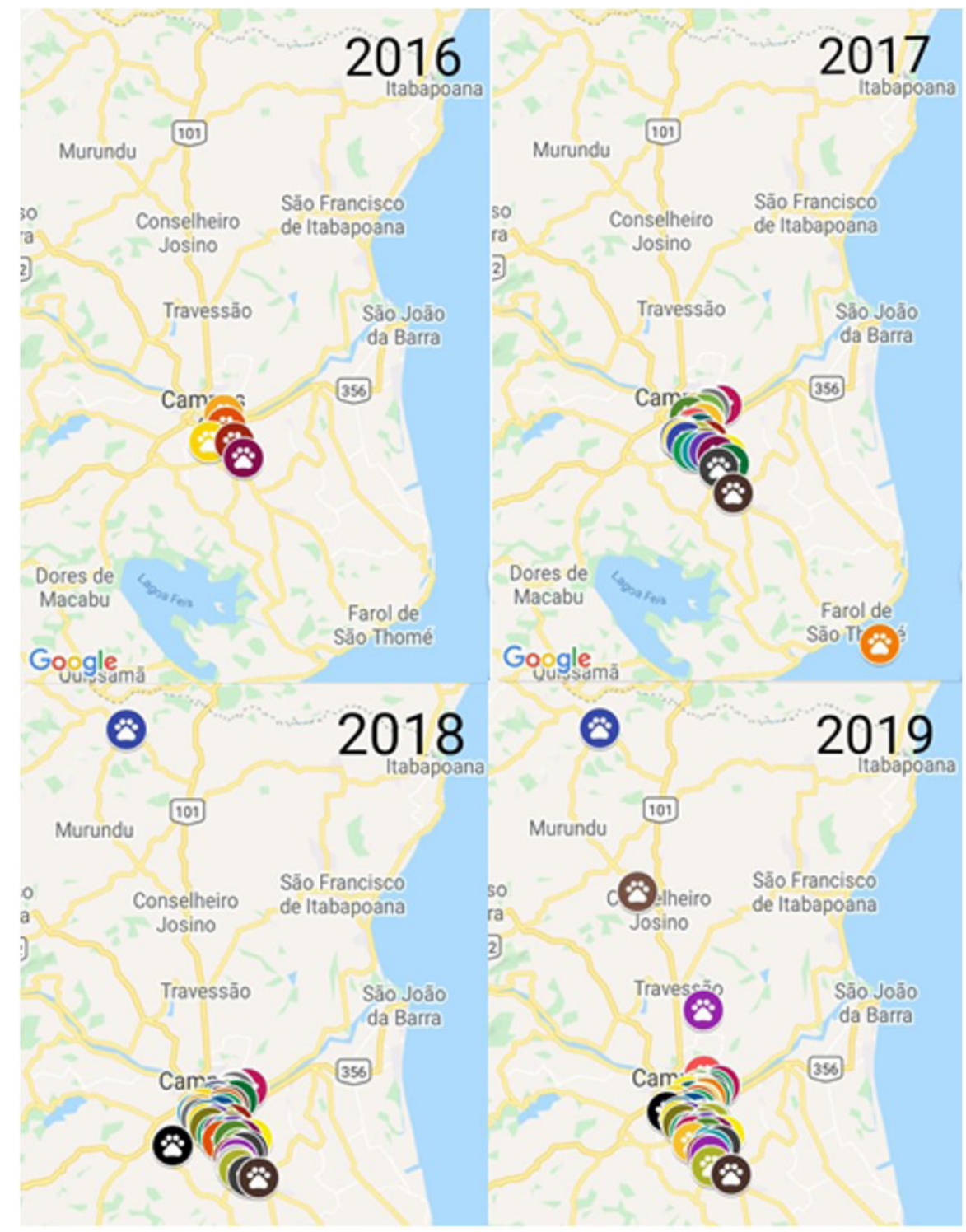

Figure 3. Geographical distribution of sporotrichosis. Note. Geographical distribution of positive animal cases in the neighborhoods of Rio de Janeiro, in the period of 2016 to 2019. The icons in the map represent the neighborhoods affected, not the number of animal cases.

Source. Personal Archive.

In a study conducted by Silva et al. (2012), the cases of human sporotrichosis in the state of Rio de Janeiro and neighboring municipalities were evaluated, proving the epidemic of the disease. However, the municipality of Campos dos Goytacazes was not included in the study. It may be suggested that there were no cases of the disease in this period or they have been underreported or have not been reported by health professionals. In the current study, positive cases of animals attended in private clinics were also excluded, revealing that the number of positive cases and affected neighborhoods may be higher.

Although the evolution of the epidemic by zoonotic transmission in the state of Rio de Janeiro is considered the largest one ever described (Gremião et al., 2015; Schubach et al., 2004), the mycosis has already been reported in several states as following: Rio Grande do Sul (Brandolt et al., 2018; Mattei et al., 2011; Poester et al., 2018; Xavier et al., 2004); Paraíba (Nunes et al., 2011); Pernambuco (Araújo \& Leal, 2016); and Mato Grosso (Fernandes et al., 2004). In fact, it is relevant to highlight the importance of adding sporotrichosis in the list of ulcerated cutaneous nodulous (Larsson, 
2011) and even with respiratory signs as a differential diagnosis, not only in the state of Rio de Janeiro, as well as in Brazil.

Although the current study does not assess the species causing the disease in the diagnosed animals, it is important to highlight the change of the etiological agent to S. brasiliensis, with high prevalence in strains from the states of Rio de Janeiro, São Paulo, Minas Gerais and Paraná. The species was isolated in 96.9\% of cats evaluated by Rodrigues et al. (2013b) and the genotype found in cats was identical to that isolated from humans, solidifying the theory that these animals play an important role in transmitting the disease.

Another relevant factor is that sporotrichosis is a zoonotic disease related to humans' hospitalizations and deaths all over Brazil, comprising 782 hospitalizations from 1992 to 2005 in all Brazilian states, excepted Roraima. The states with the highest number of hospitalizations were as following: Rio de Janeiro (32\%); São Paulo (16.4\%); and Goiás (8.8\%). In a study conducted in Campos dos Goytacazes with 20 human patients who were positive for sporotrichosis, 95\% had cats in the home environment (Pereira et al., 2020), which coud reveal the zoonotic potential of cats for spreading the disease. Human data may be underestimated seeing that the notification of human cases is not mandatory in all states (Falcão et al., 2019). Consequently, the knowledge of the disease by the population, especially by pet owners of cats and health professionals, is of utmost importance.

However, information about the transmission of the disease is still scarce. According to Papa et al. (2018), residents of the community Vila Joazina, in the neighborhood of Galeão in the municipality of Rio de Janeiro, answered questionnaires about sporotrichosis. At that time, 73.73\% have already heard about the disease and 68\% have recognized the fungus as its agent, whereas $72 \%$ have not known how sporotrichosis was transmitted. The study also showed that $80 \%$ of the interviewees had dogs and cats in their home environment and did not know how to avoid transmitting the disease. When questioned about animals that were positive for the disease, $52 \%$ reported abandoning the animals.

Therefore, the information concerning pet owners and the entire population is essential for the control and prophylaxis of the disease. Suspected cases must be referred for treatment, where cytological and mycological exams must be performed to confirm the disease. After getting positive results, the treatment should be initiated and the animal isolated, since these measures are considered the most important ones for controlling the disease spread (Barros et al., 2011). The importance of controling cat populations, i.e., the species with the maximum zoonotic potential, should be conveyed to pet owners for disease prevention (Barros et al., 2010).

Despite the geographical advance and the number of confirmed cases in the city of Campos dos Goytacazes, the disease is still not considered a public health problem, which facilitates its dispersion. Public agencies should assist in increasing the number of Zoonosis Control Units, providing free drug samples, cremation service and free neutering (Barros et al., 2010). For an effective control, the clinical association among veterinarians, surveillance authorities and other health professionals, as well as One Health approach, is necessary to prevent and diagnose more cases (Gremião et al., 2020).

\section{Conclusion}

The present work demonstrated the wide evolution of the geographical spread of sporotrichosis in the neighborhoods and districts of the city of Campos dos Goytacazes, in the state of Rio de Janeiro, for mapping the positive animals cases from 2016 to 2019. It was concluded, accordingly, that the city already faces an epidemic situation and the disease should not be neglected by health professionals and public agencies. In fact, it is a contagious disease which facilitates its rapid transmission. Control and prophylaxis measures should be implemented and also known by the population, especially about the zoonotic potential of the disease as well as new studies on treatments to reduce and facilitate treatment for animals and their pet owners should be developed. 


\section{Acknowledgements}

We woul like to thank the Laboratorio de Sanidade Animal (UENF) for the help on the disease's diagnosis, to DSc. Adriana Jardim de Almeida for getting the funding for the project and help reviewing the manuscript and to the graduate students who helped in the clinical examinations and collecting data for this study.

\section{Ethics statement}

The clinical consultation and diagnosis of sporotrichosis has been approved at the Animal Use Ethics Committee (CEUA - UENF) with protocol number 334 and all exams were consented by the animal's owners.

\section{Financial support}

GMP, LCA and PRM - Received scholarship from UENF (Universidade Estadual do Norte Fluminense Darcy Ribeiro). AOF and GDG - Received scholarchip from CNPq (Conselho Nacional de Desenvolvimento Científico e Tecnológico). AJA and OVM - none

\section{Conflict of interests}

GMP, AOF, AJA, GDG, LCA, PRM and OVM - No conflict of interest

\section{Authors' contributions}

GMP and AOF - Preparation, writing the inicial draft and editing manuscript. AJA-Acquisition of the financial support for the project leading to this publication, review and editing manuscript. GDG, LCA and PRM - Application of statistical study data. OVM - Development of methodology.

\section{Availability of complementary results}

ALMEIDA, AJ.; REIS, NF.; LOURENÇO, CS.; COSTA, NQ.; BERNARDINO, MLA.; VIEIRA-DA-MOTTA, O. Esporotricose em felinos domésticos (Felis catus domesticus) em Campos dos Goytacazes, RJ. 2018. Pesq. Vet. Bras., 38(07):1438-1443. DOI:10.1590/1678-5150-pvb-5559.

PEREIRA, GM.; ALMEIDA, AJ.; VIERA-DA-MOTTA, O.; NAHN JUNIOR, EP; FÉLIX, AO.; ARAÚJO, LC; MARQUES, PR.; LIMA, BFD; GODINHO, ABFR. Zoonotic transmission of sporotrichosis in Campos dos Goytacazes, Rio de Janeiro, Brazil. Agrociencia, 54(4):41-54, 2020.

The work was carried out at Laboratório de Sanidade Animal and Laboratório de Clínica e Cirurgia Animal, Departamento de Medicina Veterinária, Universidade Estadual do Norte Fluminense Darcy Ribeiro, Campos dos Goytacazes, RJ, Brazil.

\section{References}

Almeida-Paes, R., Oliveira, M. M. E., Freitas, D. F. S., Valle, A. C. F., Zancopé-Oliveira, R. M., \& Gutierrez-Galhardo, M. C. (2014). Sporotrichosis in Rio de Janeiro, Brazil: Sporothrix brasiliensis is associated with atypical clinical presentations. PLoS Neglected Tropical Diseases, 8(9), e3094. https://doi.org/10.1371/journal.pntd.0003094.

Araújo, A. K. L., \& Leal, C. A. S. (2016). Esporotricose felina no município de Bezerros, Agreste Pernambucano: Relato de caso. Pubvet, 10(11), 816-820. http://dx.doi.org/10.22256/pubvet.v10n11.816-820.

Barros, M. B. L., de Almeida Paes, R., \& Schubach, A. O. (2011). Sporothrix schenckii and Sporotrichosis. Clinical Microbiology Reviews, 24(4), 633-654. http://dx.doi.org/10.1128/CMR.00007-11. PMid:21976602.

Barros, M. B. L., Schubach, A. O., Schubach, T. M. P., Wanke, B., \& Lambert-Passos, S. R. (2008). An epidemic of Sporotrichosis in Rio de Janeiro, Brazil: Epidemiological aspects of a series of cases. Epidemiology and Infection, 136(9), 1192-1196. http://dx.doi.org/10.1017/S0950268807009727. PMid:18028580.

Barros, M. B. L., Schubach, T. P., Coll, J. O., Gremião, I. D., Wanke, B., \& Schubach, A. (2010). Sporotrichosis: Development and challenges of an epidemic. Revista Panamericana de Salud Pública, 27(6), 455-460. PMid:20721446.

Barros, M. B., Schubach, ADE. O., do Valle, A. C., Gutierrez Galhardo, M. C., Conceição-Silva, F., Schubach, T. M., Reis, R. S., Wanke, B., Marzochi, K. B., \& Conceição, M. J. (2004). Cat transmitted Sporotrichosis epidemic in Rio de Janeiro, Brazil: Description of a series of cases. Clinical Infectious Diseases, 38(4), 529-535. http://dx.doi. org/10.1086/381200. PMid:14765346. 
Brandolt, T. M., Madrid, I. M., Poester, V. R., Sanchotene, K. O., Basso, R. P., Klafke, G. B., Rodrigues, M. L., \& Xavier, M. O. (2018). Human Sporotrichosis: A zoonotic outbreak in southern Brazil, 2012-2017. Medical Mycology, 57(5), 527-533. http://dx.doi.org/10.1093/mmy/myy082. PMid:30265327.

Bustamante, B., \& Campos, P. E. (2004). Sporotrichosis: A forgotten disease in the drug research agenda. Expert Review of Anti-Infective Therapy, 2(1), 85-94. http://dx.doi.org/10.1586/14787210.2.1.85. PMid:15482174.

Etchecopaz, A. N., Lanza, N., Toscanini, M. A., Devoto, T. B., Pola, S. J., Daneri, G. L., Iovannitti, C. A., \& Cuestas, M. L. (2020). Sporotrichosis caused by Sporothrix brasiliensis in Argentina: Case report, molecular identification and in vitro susceptibility pattern to antifungal drugs. Journal de Mycologie Médicale, 30(1), 100908. http:// dx.doi.org/10.1016/i.mycmed.2019.100908. PMid:31732417.

Ettinger, S. J., \& Feldman, E. C. (2000). Tratado de Medicina Interna Veterinária - Doenças do cão e do gato. (5. ed.) Barueri: Guanabara Koogan.

Falcão, E. M. M., de Lima Filho, J. B., Campos, D. P., Valle, A. C. F., Bastos, F. I., Gutierrez-Galhardo, M. C., \& Freitas, D. F. S.. (2019). Hospitalizations and deaths related to sporotrichosis in Brazil (1992-2015). Cadernos de Saude Publica, 35(4), e00109218. http://dx.doi.org/10.1590/0102-311x00109218. PMid:31066776.

Fernandes, C. G. N., Moura, S. T., Dantas, A. F. M., \& Blatt, M. C. S. (2004). Esporotricose felina: aspectos clínicoepidemiológicos: relato de casos (Cuiabá, Mato Grosso, Brasil). MEDEVEP Revista Científica de Medicina Veterinária, 2(5), 39-43. https://pesquisa.bvsalud.org/portal/resource/pt/vti-340

Fernandes, G. F., dos Santos, P. O., Rodrigues, A. M., Sasaki, A. A., Burger, E., \& de Camargo, Z. P. (2013). Characterization of virulence profile, protein secretion and immunogenicity of different Sporothrix schenckii sensu stricto isolates compared with S. globosa and S. brasiliensis species. Virulence, 4(3), 241-249. http://dx.doi.org/10.4161/ viru.23112. PMid:23324498.

Freitas, D. F., do Valle, A. C., de Almeida Paes, R., Bastos, F. I., \& Galhardo, M. C. (2010). Zoonotic Sporotrichosis in Rio de Janeiro, Brazil: A protracted epidemic yet to be curbed. Clinical Infectious Diseases, 50(3), 453. http:// dx.doi.org/10.1086/649891. PMid:20064034.

Gremião, I. D. F., Menezes, R. C., Schubach, T. M. P., Figueiredo, A. B. F., Cavalcanti, M. C. H., \& Pereira, S. A. (2015) Feline sporotrichosis: Epidemiological and clinical aspects. Medical Mycology, 53(1), 15-21. http://dx.doi. org/10.1093/mmy/myu061. PMid:25477076.

Gremião, I. D. F., Miranda, L. H. M., Reis, E. G., Rodrigues, A. M., \& Pereira, S. A. (2017). Zoonotic epidemic of Sporotrichosis: Cat to human transmission. PLoS Pathogens, 13(1), e1006077. http://dx.doi.org/10.1371/journal. ppat.1006077. PMid:28103311.

Gremião, I. D. F., Oliveira, M. M. E., Monteiro de Miranda, L. H., Saraiva Freitas, D. F., \& Pereira, S. A. (2020). Geografic expansion of Sporotrichosis, Brazil. Emerging Infectious Diseases, 26(3), 621-624. http://dx.doi.org/10.3201/ eid2603.190803. PMid:32091376.

Lacaz, C. S., Porto, E., Heins-Vaccari, E. M., \& Melo, N. T. (1998). Guia para identificação de fungos, actinomicetos e algas. São Paulo: Sarvier.

Larsson, C. E. (2011). Esporotricose. Brazilian Journal of Veterinary Research and Animal Science, 48(3), 250-259. http://dx.doi.org/10.11606/S1413-95962011000300010.

Mattei, A. S., Madrid, I. M., Santin, R., Silva, F. V., Carapeto, L. P., \& Meireles, M. C. A. (2011). Sporothrix schenckii in a hospital and home environment in the city of Pelotas/RS - Brazil. Anais da Academia Brasileira de Ciências, 83(4), 1359-1362. http://dx.doi.org/10.1590/S0001-37652011000400022. PMid:22146963.

Montenegro, H., Rodrigues, A. M., Dias, M. A., da Silva, E. A., Bernardi, F., \& de Camargo, Z. P. (2014). Feline sporotrichosis due to Sporothrix brasiliensis: An emerging animal infection in São Paulo, Brazil. BMC Veterinary Research, 10(269), 269. http://dx.doi.org/10.1186/s12917-014-0269-5. PMid:25407096.

Nunes, G. D. L., Carneiro, R. S., Filgueira, K. D., Filgueira, F. G. F., \& Fernandes, T. H. T. (2011). Esporotricose felina no município de Itaporanga, estado da Paraíba, Brasil: Relato de um caso. Arquivos de Ciências Veterinárias e Zoologia da UNIPAR, 14(2), 157-161. https://revistas.unipar.br/index.php/veterinaria/article/view/4152/2594

Papa, M. G. O., Oliveira, M. H., Reis, L. L. M., Camera, P. O., \& Silva, A. C. R. (2018). Avaliação do conhecimento dos moradores da Zona Norte do Rio de Janeiro em relação à esporotricose. Revista Brasileira de Educação e Saúde, 8(4), 65-70. http://dx.doi.org/10.18378/rebes.v8i4.6111.

Pereira, G. M., Almeida, A. J., Viera-Da-Motta, O., Nahn Junior, E. P., Félix, A. O., Araújo, L. C., Marques, P. R., Lima, B. F. D., \& Godinho, A. B. F. R. (2020). Zoonotic transmission of sporotrichosis in Campos dos Goytacazes, Rio de Janeiro, Brazil. Agrociencia, 54(4), 41-54.

Poester, V. R., Mattei, A. S., Madrid, I. M., Pereira, J. T. B., Klafke, G. B., Sanchotene, K. O., Brandolt, T. M., \& Xavier, M. O. (2018). Sporotrichosis in Southern Brazil, towards an epidemic? Zoonoses and Public Health, 65(7), 815. http://dx.doi.org/10.1111/zph.12504. PMid:30009528.

Queiroz-Telles, F., Nucci, M., Colombo, A. L., Tobón, A., \& Restrepo, A. (2011). Mycoses of implantation in Latin America: An overview of epidemiology, clinical manifestations, diagnosis and treatment. Medical Mycology, 49(3), 225-236. http://dx.doi.org/10.3109/13693786.2010.539631. PMid:21128710.

Rodrigues, A. M., de Hoog, S., \& de Camargo, Z. P. (2013a). Emergence of pathogenicity in the Sporothrix schenckii complex. Medical Mycology, 51(4), 405-412. http://dx.doi.org/10.3109/13693786.2012.719648. PMid:22989196. 
Rodrigues, A. M., de Melo Teixeira, M., de Hoog, G. S., Schubach, T. M., Pereira, S. A., Fernandes, G. F., Bezerra, L. M., Felipe, M. S., \& de Camargo, Z. P.. (2013b). Phylogenetic analysis reveals a high prevalence of Sporothrix brasiliensis in feline sporotrichosis outbreaks. PLoS Neglected Tropical Diseases, 7(6), e2281. http://dx.doi. org/10.1371/journal.pntd.0002281. PMid:23818999.

Rodrigues, A. M., de Hoog, G. S., \& de Camargo, Z. P. (2016). Sporothrix species causing outbreaks in animals and humans driven by animal-animal transmission. PLoS Pathogens, 12(7), e1005638. http://dx.doi.org/10.1371/ journal.ppat.1005638. PMid:27415796.

Schubach, T. M. P., Schubach, A., Okamoto, T., Barros, M. B. L., Figueiredo, F. B., Cuzzi, T., Fialho-Monteiro, P. C. F., Reis, R. S., Perez, M. A., \& Wanke, B. (2004). Evaluation of an epidemic of sporotrichosis in cats: 347 cases (1998-2001). Journal of the American Veterinary Medical Association, 224(10), 1623-1629. http://dx.doi. org/10.2460/javma.2004.224.1623. PMid:15154732.

Silva, M. B., Costa, M. M., Torres, C. C., Galhardo, M. C., Valle, A. C., Magalhães, MDE. A., Sabroza, P. C., \& Oliveira, R. M. (2012). Urban sporotrichosis: A neglected epidemic in Rio de Janeiro, Brazil. Cadernos de Saude Publica, 28(10), 1867-1880. http://dx.doi.org/10.1590/S0102-311X2012001000006. PMid:23090167.

Xavier, M. O., Nobre, M. O., Sampaio Junior, D. P., Antunes, T. Á., Nascente, P. S., Sória, F. B. A., \& Meireles, M. C. A. (2004). Esporotricose felina com envolvimento humano na cidade de Pelotas, RS, Brasil. Ciência Rural, Santa Maria, 34(6), 1961-1963. http://dx.doi.org/10.1590/S0103-84782004000600047.

Zhou, X., Rodrigues, A. M., Feng, P., \& Hoog, G. S. (2014). Global ITS diversity in the Sporothrix schenckii complex. Fungal Diversity, 66, 153-165. 